Ann. Génét. Sél. Anim., I977, 9 (I), 493-507

\title{
Meiosis in the domestic ruminants with particular reference to Robertsonian translocations ${ }^{(1)}$
}

\author{
D. N. LOGUE \\ Pig Breeding Centre \\ Leeds road, Thorpe Willoughby, \\ Selby North, Yorks YO 89 HL Great Britain
}

\section{Summary}

Male meiosis was studied in cattle, sheep and goat while female meiosis was studied in sheep. The male meiotic process of these three species showed great similarities, while the appearance of the metaphase stages of female meiosis was found to conform quite closely with those of the males save for the formation of the first polar body.

A number of bulis heterozygous for the $1 / 29$ and $14 / 20$ Robertsonian translocations have been investigated as have some rams and ewe lambs heterozygous and homozygous for the Massey I Robertsonian translocation. The abnormal meiotic configuration caused by the pairing of the translocation chromosome in these cases was easily identified in the stages of diplotene and diakinesis, although the anomalies did not seem to affect chiasma formation.

In metaphase II cells, a small number of hyperhaploid secondary spermatocytes and oocytes, possessing one extra autosome were identified, a higher level of non-disjunction being found in the heterozygous animals than in the normal. One could postulate that these hypermodal cells were formed by malsegregation of the trivalent at anaphase $I$, but while this formation is compatible with fertility data in cattle this is not so in sheep, possibly due to a variety of selection factors.

\section{Introduction}

The chromosomes of the domestic ruminants were first identified using gonadal tissue initially from histological and subsequently from meiotic preparations (MAKINo et NishimuRa, I952). Such methods have been totally superceded by tissue culture techniques but meiotic investigations are still of value for 3 main reasons.

Firstly the presence of structural re-arrangements of the karyotype are easily recognised in meiotic prophase especially the stage of diakinesis. This applies even to re-arrangements studied by $Q$ - and G-bands (HULTEN et LINDSTEN, I973).

Secondly, the study of chiasma formation at diakinesis has been of considerable interest as it is generally believed that the mean number of chiasma at diakinesis in a particular species gives important information concerning the

(I) This article has been presented to the 3 rd Colloquium on Cytogenetics of Domestic animals, May 3r-June 2, I977, Jouy-en-Josas, France. 
genetic length of that species (HENDERSON, I969). As an extension of this hypothesis it has been postulated that chiasma positions at diakinesis while not necessarily being coincident with crossing-over points may nevertheless be related to them. As yet this has not received general acceptance (HULTEN, 1974).

Finally, meiotic studies can be used to obtain an estimate of irregular segregation based on chromosome counts of meiotic metaphase II (MII) (FORD et Evans, I973).

The present investigations were broadly based on these uses. The first objective was to compare the mean overall chiasma count of the three major domestic species the cow, sheep and goat. Their somatic karyotypes are extremely similar (MELANDER, I959) and so it was thought to be of interest to compare their genetic length using meiotic information, since at present this is impossible by genetic means. The second objective was to use meiotic preparations to confirm several presumptive Robertsonian translocations in cattle and sheep by the presence of a trivalent at diakinesis. The third objective, which followed from the second was to determine if possible wheter the presence of such translocations had any effect upon phenotype, gametogenesis, chiasma count and position at diakinesis and wheter their presence increased the rate of non-disjunction or irregular segregation based on MII counts.

\section{Materials and Methods}

The animals studies are shown in Table $r$. All the sheep were taken from a small flock developed from 4 New Zealand Romney tups heterozygous for the Massey I Robertsonian translocation. These were kindly sent to the U.K. by Professor BRUERE of New Zealand. The one goat and 25 of the normal bulls were studied at slaughter. The remainder of the bulls and all the rams were clinically examined. This included a semen test.

TABLE I

Material

Materiel

\begin{tabular}{|c|c|c|c|c|c|c|c|}
\hline & & & & Normal & $\begin{array}{l}\text { R. T. Heterozy- } \\
\text { gote }\end{array}$ & \multicolumn{2}{|c|}{ Type R. T. } \\
\hline SHEEP & $\begin{array}{l}\text { - male. } \\
\text { — female }\end{array}$ & & $\cdot$ & $\begin{array}{l}2 \\
8\end{array}$ & $\begin{array}{l}5 \\
5\end{array}$ & $\begin{array}{c}\text { Masse I } \mathrm{t}(5,26 \\
\text { BRUERE et al., }\end{array}$ & 1974 \\
\hline GoAT & - male & . & . & I & o & 一 & \\
\hline Cattee & - male. & . & $\cdot$ & 33 & $\begin{array}{l}6 \\
2\end{array}$ & $\begin{array}{l}\text { I /29 READING } \\
14 / 20 \text { READING }\end{array}$ & $\begin{array}{l}\text { HARVEY, I974. } \\
\text { LOGUE et HAR- } \\
\text { VEY. unpublished } \\
\text { information. }\end{array}$ \\
\hline
\end{tabular}



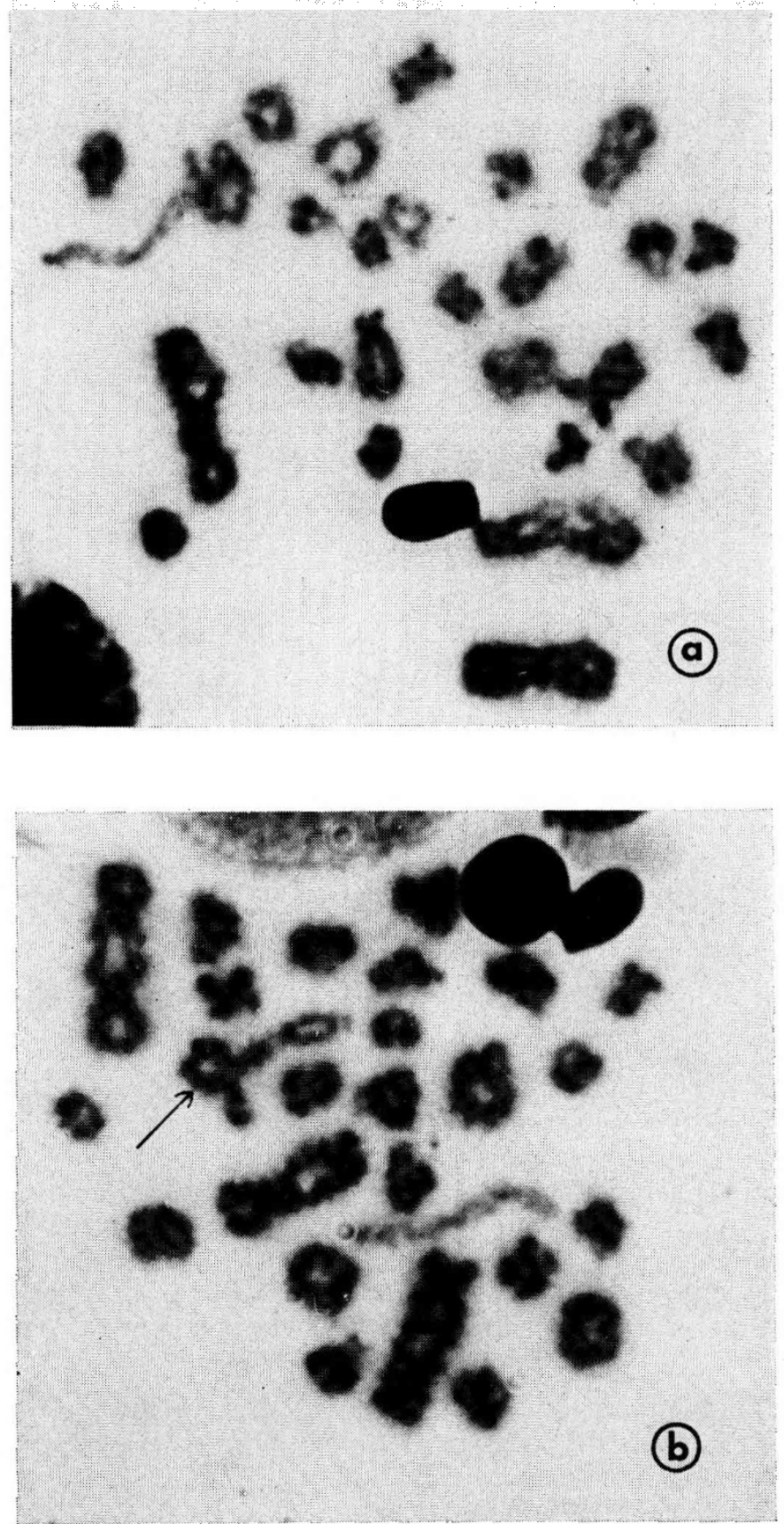

FIG. I. - a) Diakinesis Ram $M I, 27 X Y$.

b) Diakinesis Ram $M I, 26 X Y, I I I(5,26)$.

a) Diacinèse bélier $M r, 27 X Y$.

b) Diacinèse bélier $M I, 26 X Y, I I I(5,26)$. 


\section{TABLE 2}

Results - Normal karyotype: overall chiasma court Caryotype normale: nombre total de chiasma

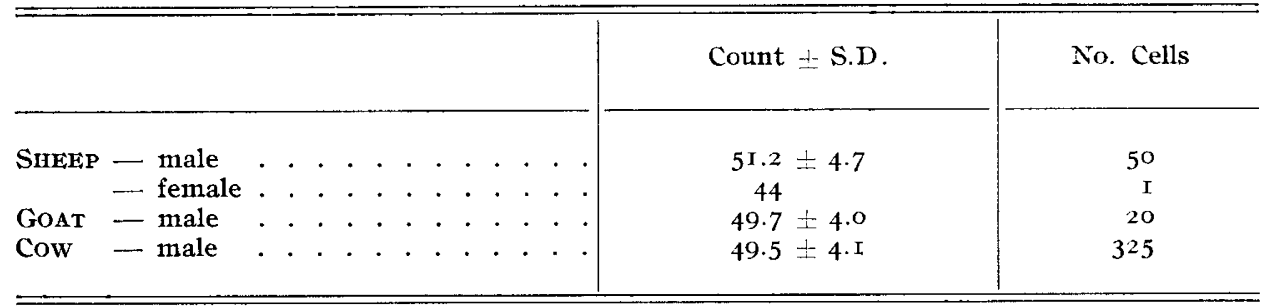

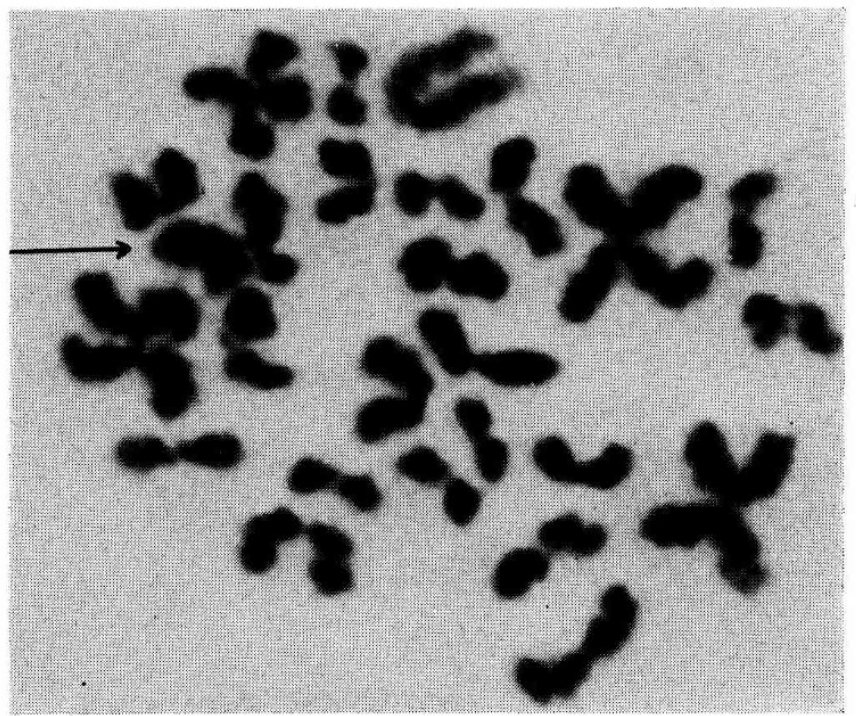

Frc. 2. - Unbalanced? secondary spermatocyte Ram $M_{I I} 27 ? X, t(5,26)+$ ? Spermatocyte II déséquilibre? Bélier $M_{I I}, 27$ ? $X, t(5,26)+$ ?

\section{TABLE 3}

Results - Heterozyogote overăll chiasma counts

Nombre total de chiasma chez les hétérozygotes

\begin{tabular}{|c|c|c|}
\hline & Count \pm S.D. & No. Cells \\
\hline 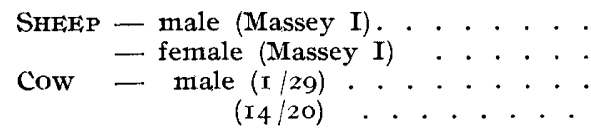 & $\begin{array}{l}50.9 \pm 4 \cdot I \\
44 \pm 3 \cdot 3 \\
47.8 \pm 4 \cdot 2 \\
48.1 \pm 3.9\end{array}$ & $\begin{array}{r}100 \\
7 \\
\times 50 \\
25\end{array}$ \\
\hline
\end{tabular}


TABLE 4

Comparison of the distribution of chiasma

in the I/29 trivalent and normal bivalent No. I

Comparaison entre la distribution des chiasma du trivalent $I / 29$

et $d u$ bicalent $n^{\circ}$ I normal

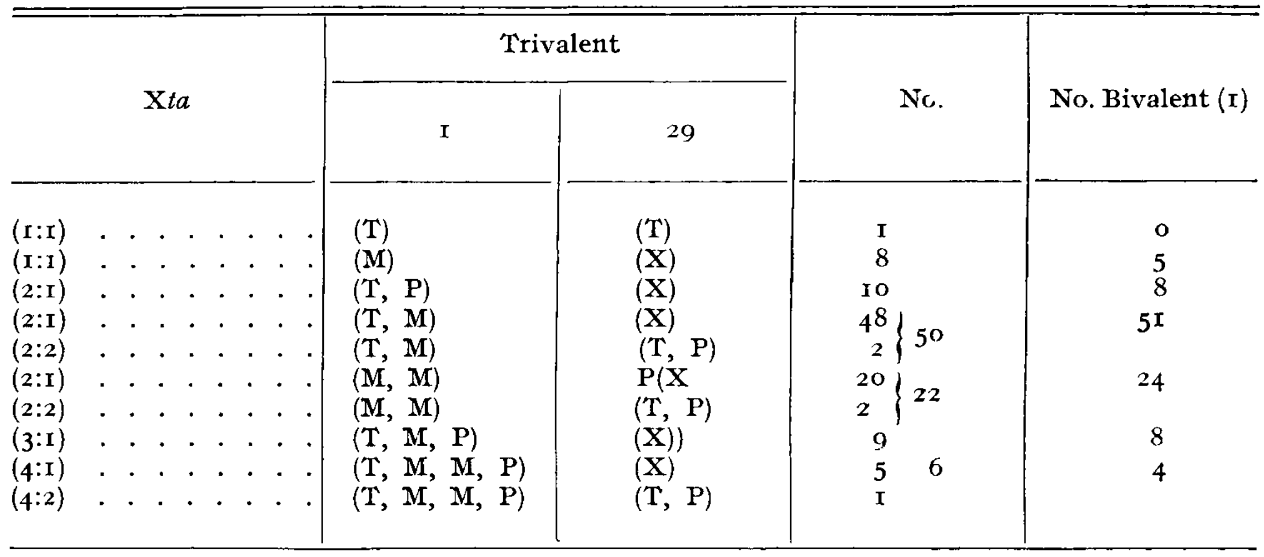

$\mathrm{X}=$ Not defined.

$\mathrm{T}=$ Terminal.

$\mathbf{M}=$ Median.

$\mathbf{P}=$ Proximal.

TABLE 5

Results - Chromosome counts of MII cells - Bull

Nombre de chromosomes dans les metophases II des travaux

\begin{tabular}{|c|c|c|c|c|c|c|c|c|c|c|c|c|c|}
\hline \multirow{5}{*}{\multicolumn{2}{|c|}{$\begin{array}{l}\text { No. of chromosomes. } \\
\text { Normal Bulls . } \\
\text { r / } 29 \text { heterozygotes } \\
\text { I } 4 / 20 \text { heterozygotes }\end{array}$}} & \multirow{5}{*}{\multicolumn{2}{|c|}{. }} & \multirow{5}{*}{\multicolumn{2}{|c|}{ 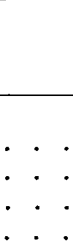 }} & \multicolumn{4}{|c|}{$\begin{array}{l}\text { Translocation } \\
\text { Identified }\end{array}$} & \multicolumn{4}{|c|}{ No translocation } \\
\hline & & & & & & 27 & 28 & 29 & 30 & 28 & 29 & 30 & $3 I$ \\
\hline & & & & & & & & & & 35 & $5^{2}$ & 506 & 8 \\
\hline & & & & & & 8 & 23 & I 28 & 7 & 7 & 25 & I 85 & 5 \\
\hline & & & & & & 2 & 3 & 28 & I & 3 & 3 & 22 & 1 \\
\hline
\end{tabular}

Rate of non-disjunction $\left(^{*}\right)$. . . . . . . $\mathrm{R}_{1} \quad \mathrm{R}_{2}$

Normal . . . . . . . . . . . . . $\overline{2.8 \text { or IO.6 }}$

$\Upsilon / 29$ Heterozygote. . . . . . . . . . 6.4 or $16.1 \quad(\mathrm{P}<0.05)$

I4/20 Heterozygote. . . . . . . . . 6.8 or 13.8 (P>0.05)

(*) As Ford and Fivans, I973. 


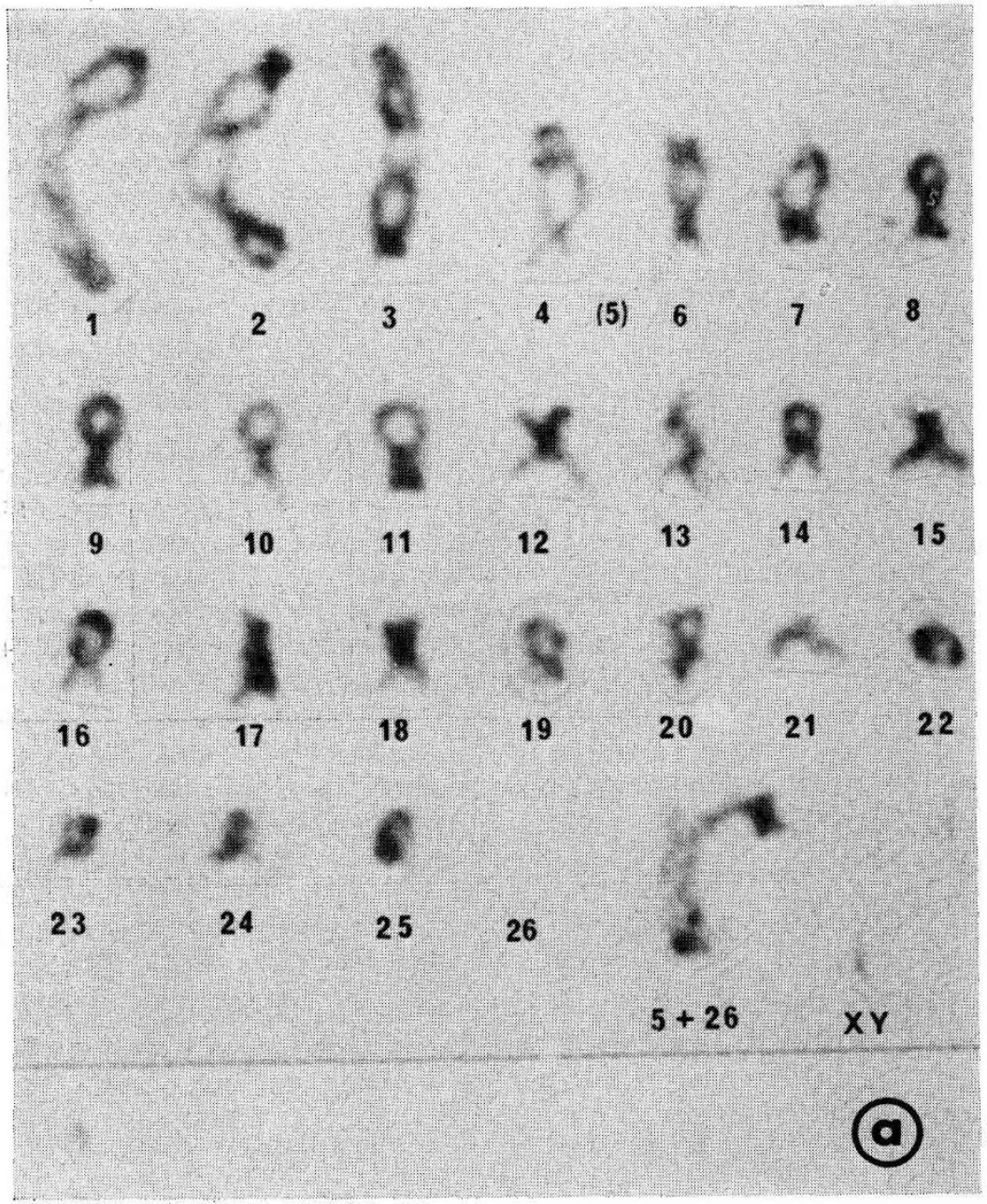

FIG. 3. - a) Karyotype Diakinesis Ram $M I, 26 X Y$, III $(5,26)$.

a) Caryotype d'une diacinèse du bélier $M I, 26 X Y, I I I(5,26)$.

The somatic karyotype of all the animals were studied, if possible from two tissues. In the males testicular tissue was removed by biopsy, castration or at slaughter. Portions of the testes were then processed meiotically (LoGUE, I975) and histologically. In the heterozygous bulls and three normal halfsibs two parameters of testicular function, Leydig Cell Volume and total relative tubule length were computed from the histological sections (AHMAD et al., I97I).

Female meiosis was studied utilising oocytes matured in vitro from 4-6 week old prepubertal lambs (LOGUE et al. in preparation).

The various meiotic stages were identified, in particular, diakinesis and MII. At diakinesis overall chiasma counts were made and any abnormal configurations, e.g. trivalents noted. The chiasma positions on the largest bivalent (No. I) 


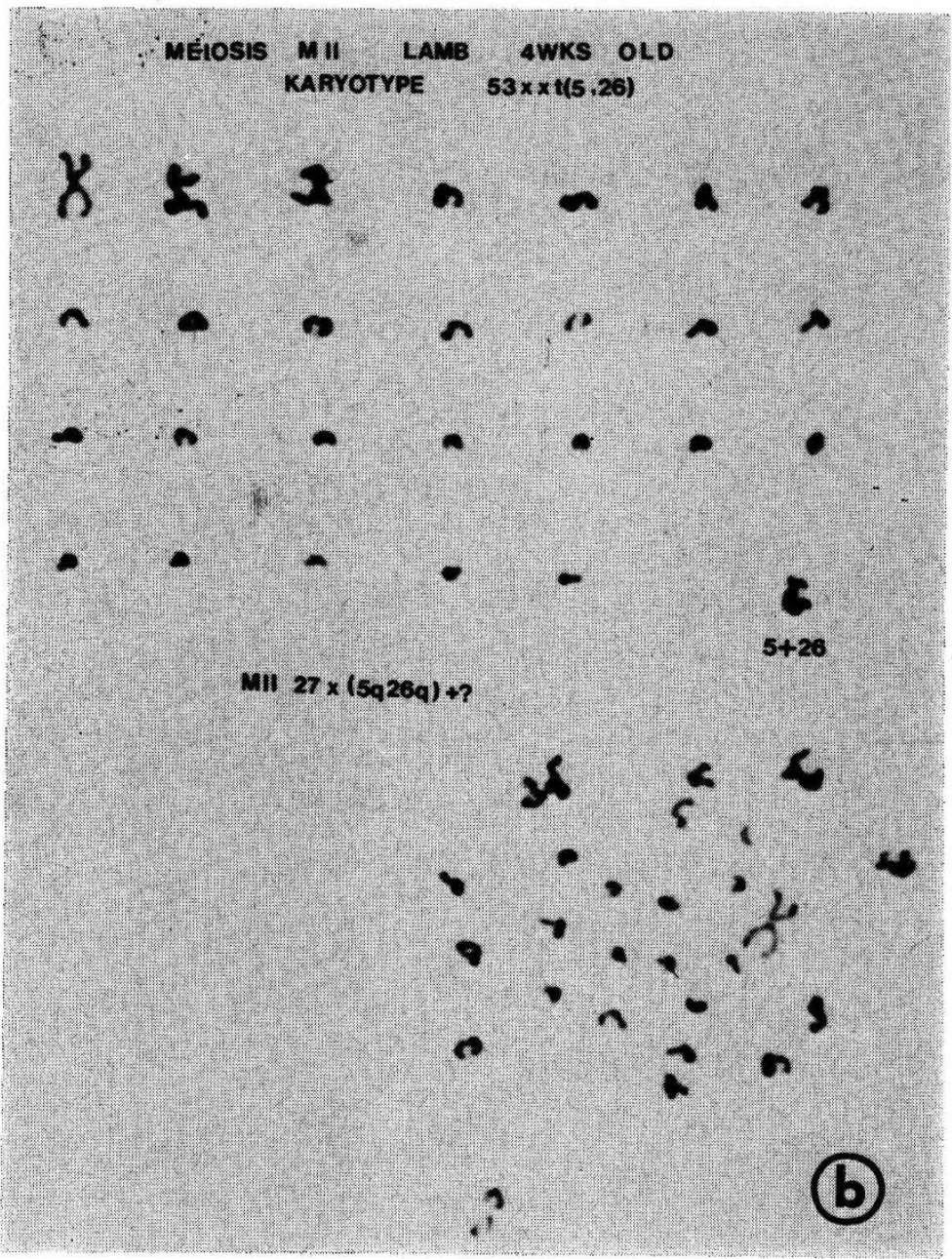

FIG. 3. - b) Karyotype unbalanced? oocyte lamb $M_{I I}: 27 ? X, t(5,26)+$ ?

b) Caryotype déséquilibré d'oocyte.

were noted in normal bulls and compared with those on the No. I arm of the I $/ 29$ trivalent.

At MII chromosome counts were made of all suitable cells and the sex and translocation chromosomes identified where possible.

\section{Results}

All the heterozygous bulls and rams examined clinically and histologically had normal behaviour and semen quality. In the spermatogenic study Leydig cell volumes and total relative tubule length in the heterozygous bulls and their 


\section{1 \\ 81040100 \\ - $\wedge$ - \\ $-\infty<0$ ? \\ (a)}

FIG. 4. - a) Karyotype diakinesis Goat $M I, 30 X Y$.

a) Caryotype en diacinèse bouc $M I, 30 X Y$.

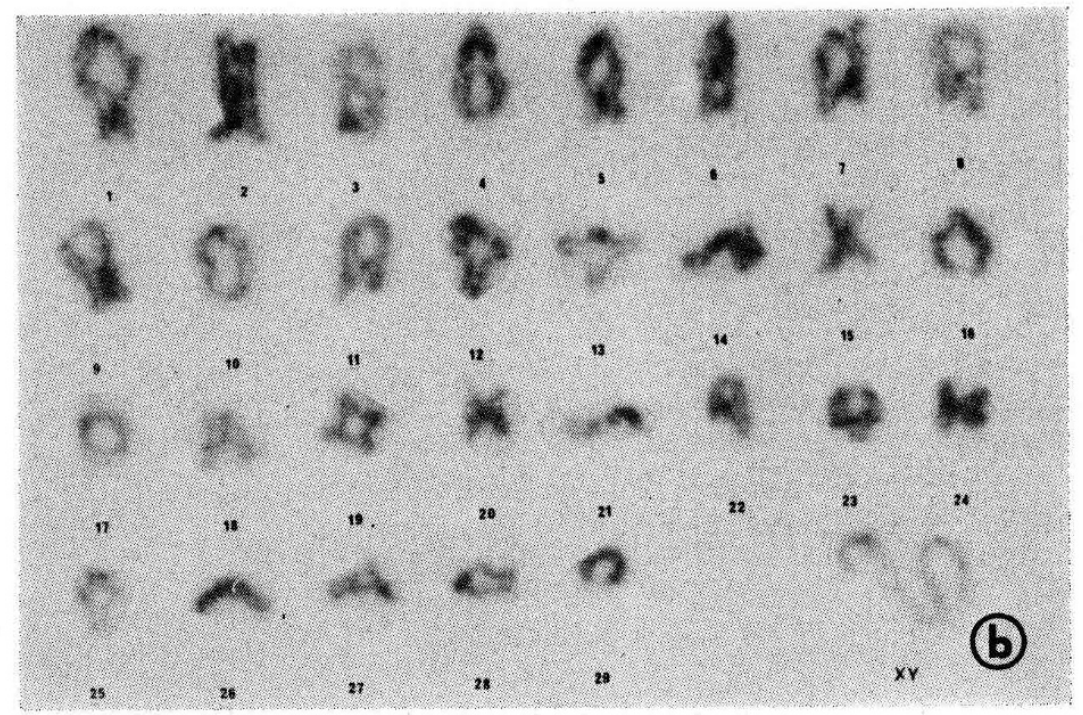

b) Karyotype diakinesis Bull $M_{I}, 30 X Y$.

b) Caryotype en diacinèse, taureau $M I, 30 X Y$. 


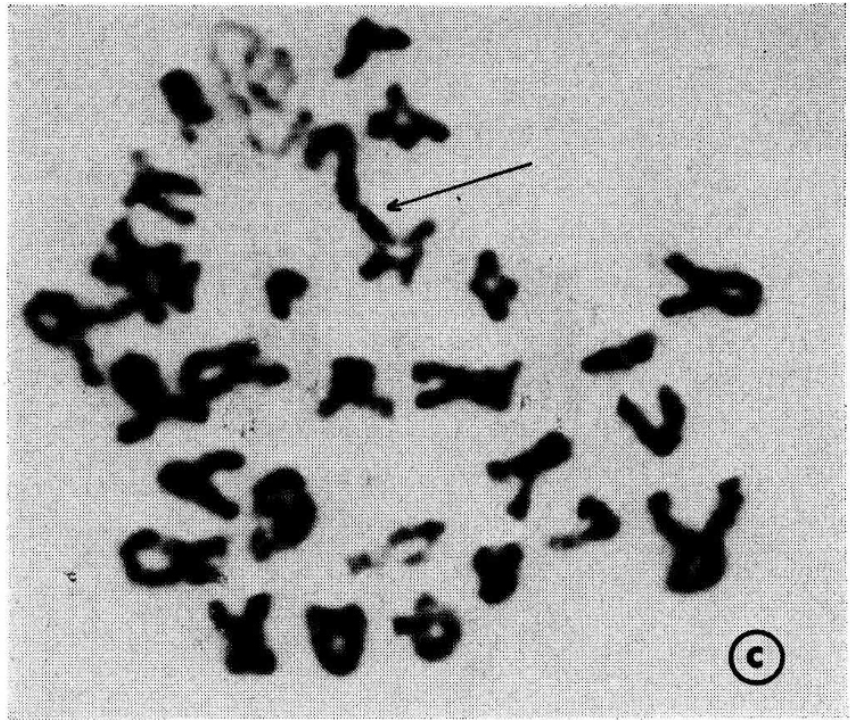

c) Diakinesis Bull $M r, 29 X Y, I I I(I 4,20)$.

c) Diacinèse, taureau $M r, 29 X Y$, III $(I 4,20)$.

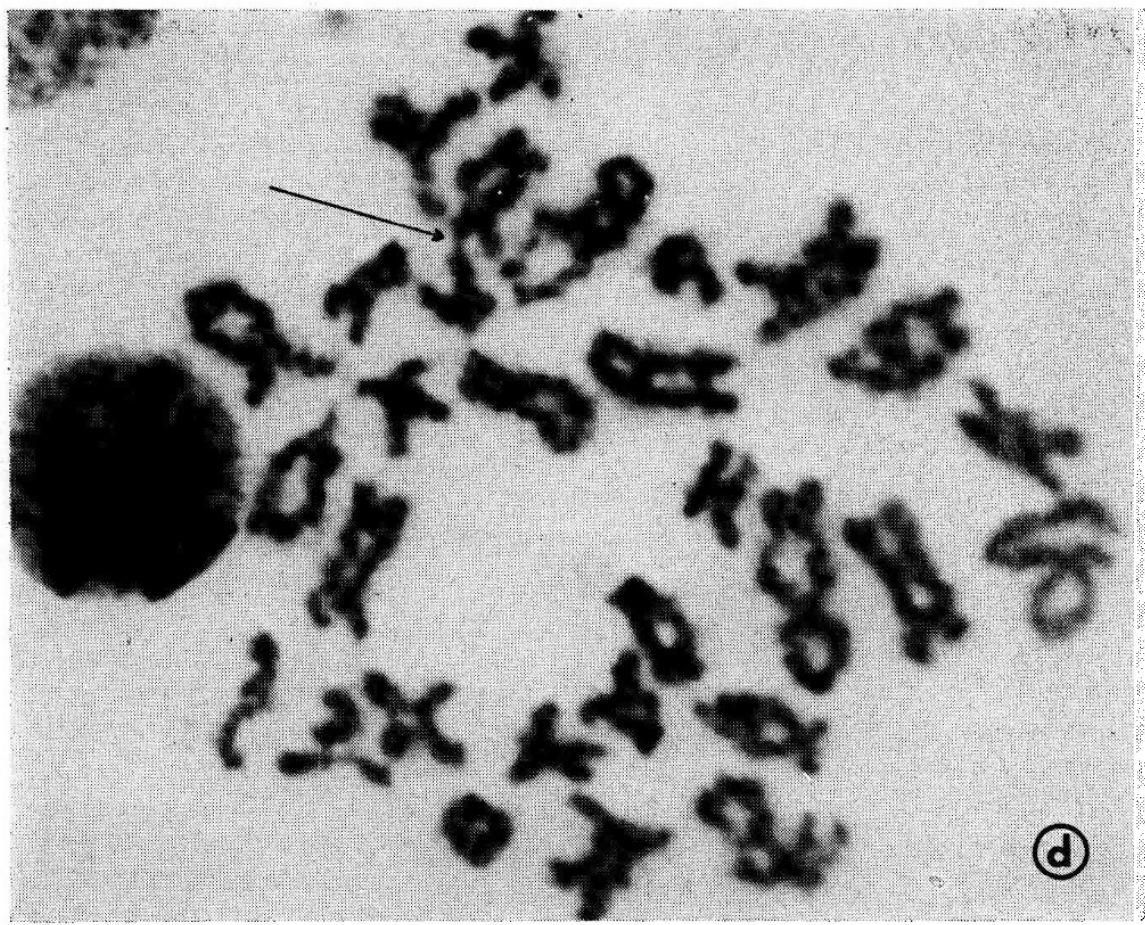

FIG. 4. - d) Diakinesis Bull $M I, 30 X Y$ (note association).

d) Diacinèse, taureau $M r, 30 X Y$ (note association). 


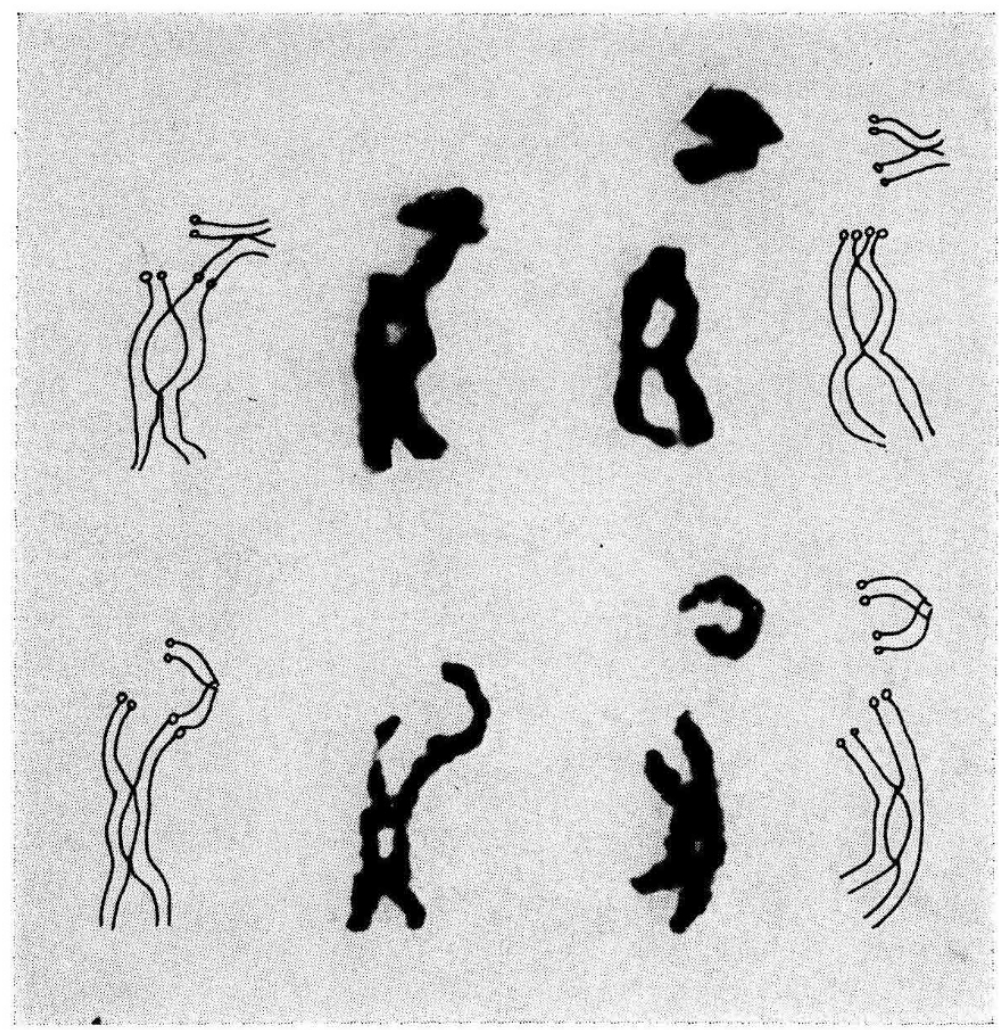

FIG. 5. - I/29 Trivalents et Normal $n^{0}$ I Bivalents.

Trivalents $I / 29$ et Bivalents $n^{0} I$ anormaux.

TABLE 6

Results - Chromosome counts of MII cells - RAMS

Nombve de chromusomes dans les metophases II chez les béliers

\begin{tabular}{|c|c|c|c|c|c|c|c|c|}
\hline \multirow{3}{*}{$\begin{array}{l}\text { No. of chromosomes . . . . . . . } \\
\text { Normal Rams . . . . . . . . . } \\
\text { Massey I heterozygotes } \\
\end{array}$} & \multicolumn{2}{|c|}{ Massey I } & \multicolumn{2}{|c|}{ Identified } & \multicolumn{4}{|c|}{ No Translocation } \\
\hline & 24 & 25 & 26 & 27 & $\begin{array}{r}25 \\
3\end{array}$ & $\begin{array}{r}23 \\
8\end{array}$ & $\begin{array}{l}27 \\
42\end{array}$ & $\begin{array}{r}28 \\
2\end{array}$ \\
\hline & 2 & I5 & 92 & 5 & I & $x 6$ & I03 & 3 \\
\hline
\end{tabular}

Rate of non-disjunction . . . . . . . . $\mathrm{R}_{\mathrm{I}} \mathrm{R}_{2}$

Normal . . . . . . . . . . . . . . . . . . $\overline{6.8 \text { or } \mathrm{I} 6.8}$

Heterozygote Male . . . . . . . . . 7.6 or $19.2(\mathrm{P}>0.05)$ 
TABLE 7

Results - Chromosome counts of MII cell - Ewe lambs

Nombre de chromosome dans les métophases oo chez les agnelles

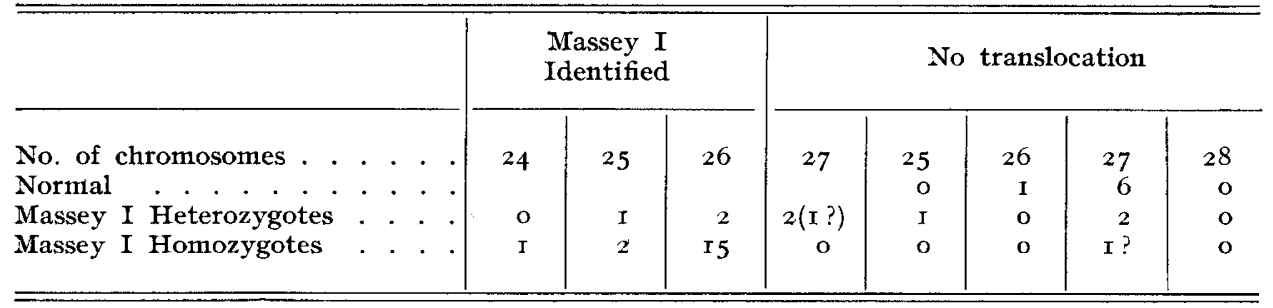

half-sibs were all found to be well within the normal range of $\mathrm{I} 5 \pm \mathrm{r} .3 \mathrm{mls}$ and $2490 \pm 585 \mathrm{~m}$ respectively (LENNOX et LOGUE in preparation).

All the stages of meiosis were identified and while the Robertsonian translocations could only be rarely seen in male pachytene, a trivalent was easily identified in diplotene and diakinesis in both sexes (fig. I-II).

The mean chiasma frequencies at diakinesis are shown in Tables 2 and 3 . Each trivalent showed a characteristic shape (fig. 2 and 3, 9-II) and a comparison of the frequencies of position in the $I / 29$ trivalent and the normal $I$ bivalent are shown in Table 4 .

The morphology of cells in MII made analysis very difficult because often sister chromatids of the autosomes were so strongly repulsed from each other as to be separate. A small number of hyper-and hypohaploid cells were counted and the results are shown in Tables 5, 6 and 7 (fig. 4 and 5, I2 and I3).

\section{Discussion}

The chiasma counts found in the normal bull, sheep and goat agree quite well with the other workers (DATTA, I970; Popescu, I97I; JAGIELLo et al., I976). These could be taken as indicating a similar gene map length in the 3 species of approximately 25 Morgans. Indeed if one estimates the Recombination Index upon the sum of the chiasma count and the haploid number (FORD, I969) this gives an even closer agreement of around the figure 80 . This agreement is most intriguing since while even the banding patterns of the somatic karyotypes are remarkably similar, somehow in the process of evolution and speciation a substantial amount of DNA (roughly Io p. cent) has either been gained by the sheep and goat or lost by the cow (Sumner et BuckLand, r976). Hence one could postulate that this "variable" DNA has no direct genetic control.

In these unselected male heterozygotes the service behaviour, semen quality and histological picture were unimpaired. Since the numbers studied are rather small and occasional reports have correlated Robertsonian translocations with impaired spermatogenesis such a correlation remains a possibility in the ruminants albeit an unlikely one (BRUERE, I975).

Meiotic investigations in the heterozygotes showed normal chiasma counts and also that the chiasma position within the trivalent itself showed no evidence of an alteration, at least in the No. I chromosome. In man alteration of both 


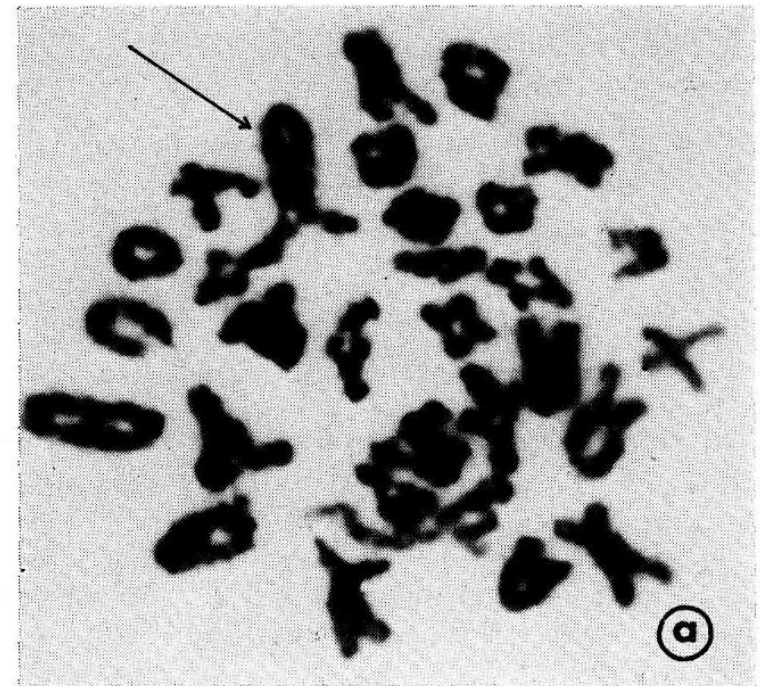

FIG. 6. - a) Diakinesis Bull $M I, 29 X Y, I I I(I, 29)$.

a) Diacinèse taureau $M I, 29 X, I I I(I, 29)$.

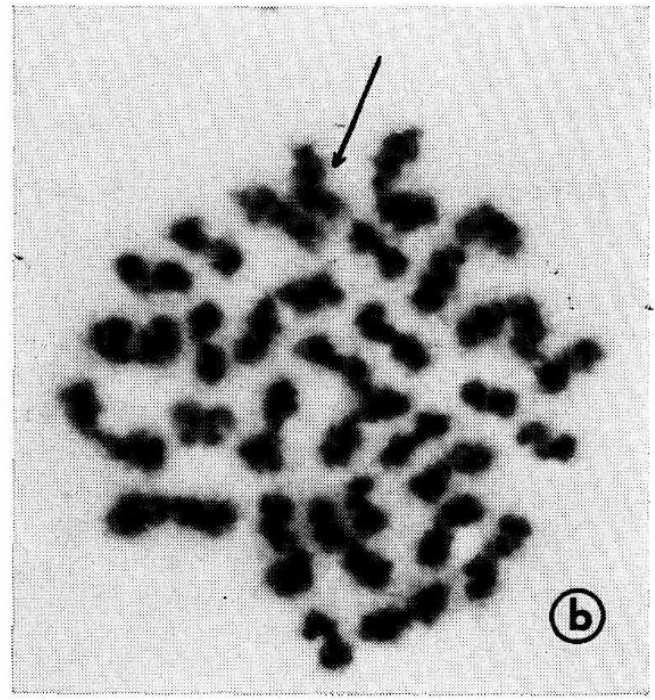

b) Secondary Spermatocyte Bull MIx, $29 Y t(I 4,20)$.

b) Spermatocyte II de taureau MII, 29 Yt $(I 4,20)$. 


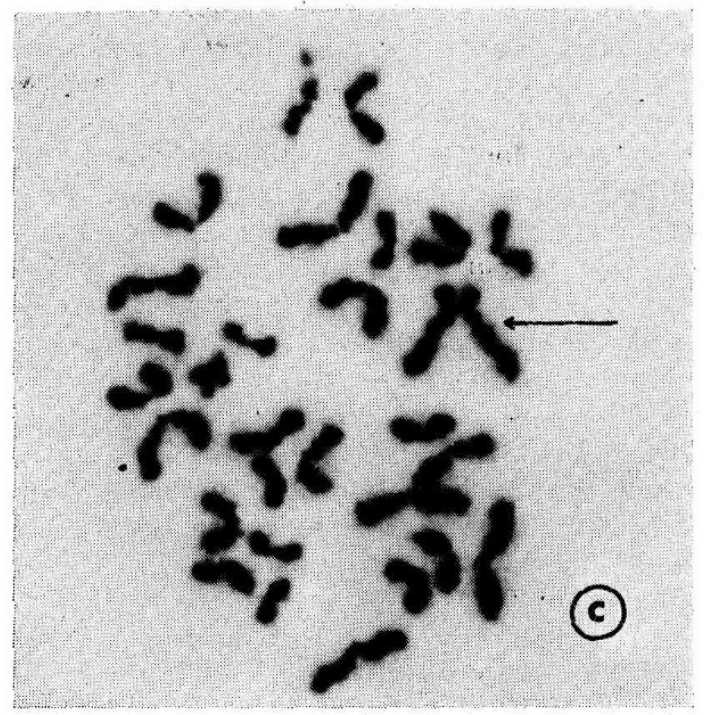

FIG. 6. - c) Secondary Spermatocyte Bull $M I I, 29 Y, t(I, 29)$.

c) Spermatocyte $I I$ de taureau $M I I, 29 Y, t(I, 29)$.

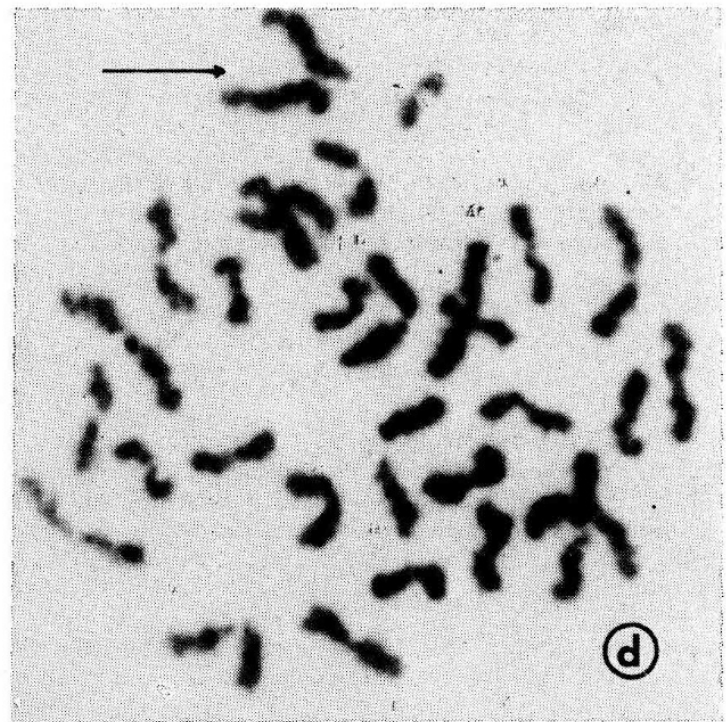

d) Unbalanced Secondary Spermatocyte Bull $M I I, 30 ? X, t(I, 29)+$ ?

d) Spermatocyte II déséquilibré de taureau $M I x, 30 ? X, t(\mathrm{I}, 29)+$ ? 
have been reported in Robertsonian translocation heterozygotes, but the significance of this is still open to question. (HuLTEN et LINDSTEN, I973).

The rates of non-disjunction based on MII counts were raised in all the heterozygous animals, although only in the $I / 29$ heterozygotes was the rise in both $R_{1}$ and $R_{\tilde{\varepsilon}}$ significant at the $5 \mathrm{p}$. cent level. Since this rise was less convincing using the $R_{2}$ estimation it remains a possibility that even in this case the data is not conclusive, however the estimated rise of non-disjunction in these bulls of around 5 p. cent agrees well with Gustavsson's I / 29 fertility data (I975). On the other hand the fertility data in the sheep do not confirm the ram non-disjunction figures (BRUERE, I975). It must be admitted the sheep data presented here are not conclusive but they do agree quite well with those of CHAPMAN et BRUERE (I975) and this concurrence leads one to postulate that there may be one or more factors operating in these heterozygous animals. Firstly there may be selection against the aneuploid gametes; secondly there may be a loss of early embryos and this has been masked in some fertility studies by normal variation in pre-implantation death; and thirdly there may be an advantage conferred upon the heterozygote itself or possibly the herd or flock as a whole by the presence of the translocation which offsets any lowered normal gametic output.

Since Robertsonian translocations have been the main method used for chromosome variation and presumably speciation in the bovidae and since these species are amongst the most successful meat producing species it is imperative we continue to attempt to understand their genetic mechanisms. It is hope this present study will stimulate others to investigate all aspects of reproductive performance and in particular the meiotic process in such animals much more fully.

Reçu pour publication en décembre 1977.

\section{Acknowledgements}

I would like to thank Professor Lennox, Mr. Hignetr, Dr. Ford and Dr. Harvey for their help and encouragement and Mrs. M. SMITH for typing the manuscript.

I would also like to acknowledge financial support from the A.R.C. and Wellcome Trust.

\section{References}

Ahmad K. N., Dykes J. R. W., Ferguson-Smith M. A., Lennox B., Mack W. S., r971. Leydig Cell Volume in chromatin-positive klinefi lter's Syndrome. J. Clin. Endocr. Metab., 33, 5I 7-552.

BRUERE A. N., I975. Further evidence of normal fertility and the formation of balanced gametes in sheep with one or more different robertsonian translocation. J. Reprod. Fert., 45, 323-33I.

Bruere A. N., Zartiman D. L., Chapman H. M., I974. The significance of the G-bands and C-bands of three different robertsonian translocations of domestic sheep. Cytogent. Cell Genet., 13, $479-488$.

Chapman H. M., Bruere A. N., I975. The frequency of aneuploidy in the secondary spermatocytes of normal and robertsonian translocation carrying rams. $J$. Reprod. Fert., 45, 333-342.

DATrA M., I970. Reinvestigation of Meiosis in the Male Goat, Capra hircus, Linn., with Special Reference to chiasma Formation in the Sex and Autosomal Bivalents. Cytologia, 35, 344-353.

FORD C. E., I909. Meiosis in Mammals in "Comparative Mammalian Cytogenetics", 9I-I06. Ed. BENIRSCh KE K., Springler-Verlag, New York, I969.

Ford C. E., Evans E. P., I973. Robertsonian translocation in mice: Segregational irregularities in male heterozygotes and zygotic unbalance. In " chromosomes today", 4, 387-397. Ed. Wahrman, J. et Lewis K. R., John Wiley et sons, N. Y. et Toronto. 
Gustavsson I., I975. New Information on the reduced Fertility of cattle with the I/29 translocation. 2nd Europ. Coll. Cytogenet. Dom. Anim., Giessen (1975), I84-188.

HARVEY M. J. A., I974. Chromosome analysis of cattle population. Vet. Rec., 95, 227.

HENDERSON S. A., I969. Chiasma localisation and incomplete pairing. In "Chromosomes today" 2, 56-60. Ed. Darlington, C. D. et Lewis, K. R., Oliver et Boyd, Edinburgh, I969.

Hulren M., I974. Chiasma distribution at diakinesis in the normal human male. Hereditas, 76, $55-78$.

Hulten H., Lindsten J., 1973. Cytogenetic aspects of human male meiosis. Adv. Hum. Genet., 4, $327-387$.

Jagiello G., Ducayen M., Fang J.-S., Graffeo J., I976. Cyclogenetic observations in mammalian oocytes. In " chromosomes today", 5, 43-63. Ed. Pearson P. L. et Lewis K. R., John Wiley et sons, N. Y. I976.

Logue D. N., I975. Ph. D. Thesis, Glasgow University.

MeLANDER Y., I959. The mitotic chromosomes of some cavicorn mammals (Bos taurus L., Bison bonasus L. et Ovis Aries L.), Heveditas, 45, 649-664.

Makino S., Nishimura I., 1952. Water pretreatment squash technique. Stain Tech., 27, r-7. Popescu C. P., I97I. Les chromosomes méiotiques du bœuf (Bos taurus L.). Ann. Génét. Sél. Anim., 3, 125-I43.

Sumner A. T., Buckland R. A., 1976. Relative DNA contents of somatic Nuclei of Ox, Shecp, and Goat. Chromosoma, 57, I7I-I 75 . 